\title{
Impact of Relationship Marketing on Export Performance: Empirical Study in Vietnamese Garment Enterprises
}

\author{
Hoang Nguyen \\ Correspondence: Hoang Nguyen, Vietnam University of Commerce, Mai Dich - Cau Giay district, Hanoi, \\ Vietnam. Tel: 84-43-764-3219. E-mail: maycay2001@yahoo.com \\ Received: October 12, 2012 \\ Accepted: November 6, 2012 \\ Online Published: November 14, 2012 \\ doi:10.5539/ibr.v5n12p133 \\ URL: http://dx.doi.org/10.5539/ibr.v5n12p133
}

\begin{abstract}
Relationship marketing is a new concept for Vietnamese enterprises. Most often based on the marketing mix 4Ps model, relationship marketing focuses on the maintenance as well as the development of relations with existing clients for mutual benefits of enterprises and customers. This paper, through theoretical and empirical analyses, investigates the interactions between internationalization process, international relationship marketing activities and export performance of Vietnamese garment enterprises. Several important recommendations to improve the export performance of the studied enterprises are drawn from the research results.
\end{abstract}

Keywords: relationship marketing, export, performance, Vietnam

\section{Introducation}

The development of the market economy, along with changes in business settings, entails close linkage among relevant factors, particularly organizations including providers, manufacturers and distributors... In the tendency towards international economic integration today, competition and co-operation relations, typically among the factors involved in export operations, have been elevated to a new height. Establishing sustainable cooperation relations among the factors therefore plays a very essential role, helping reduce expenses, generating added values for commodities, products, and to some extent, creating competitive edges for enterprises. This subject approaches the issue of relationship marketing from the points of view of Vietnamese exporters in their efforts to penetrate and improve their status in international markets.

Vietnam is a fast-growing exporter with a wide range of staple commodities ranking high on international markets, in which textile and garment are the mainstays. According to the General Statistic Office of Vietnam, in 2001, export value of textile and garment was only USD 2 billion, not in top high among the staple commodities for exports of Vietnam, then in 2010, textile and garment surpassed oil and gas, shoes and leather, aquaculture to become the commodity with greatest export turnover. In the role of a "leading export", in 2011, textile and garment export throughout the country reached USD 14 billion, accounting for $14.54 \%$ of the total export turnover nationwide and always maintained the lead in the table of Vietnam's key exports. By July 2012, export of the month reached USD 1.44 billion, increasing by $5.8 \%$ compared with the previous month, bringing this commodity export value of the first 7 months of 2012 to USD 8.27 billion, increasing by $9.3 \%$ compared with the same period in 2011. WTO statistics have shown that Vietnam is the 7th largest exporter in the world's textile and garment map, with its main markets including the United States, EU, Japan, Canada and Russia. Nevertheless, our country's export at present is facing many challenges, for example, the global crisis is leaving bad influences, competition becomes fiercer, products for export are usually processed goods of not high value, and the trade name of Vietnam textile and garment has not been widely known on international markets.

The difficulties and challenges confronting the textile and garment industry, particularly textile and garment exporters of Vietnam, come from various objective causes, namely global crisis, international trade barriers, as well as subjective causes of Vietnamese enterprises. On the other hand, domestic marketing research is heavily influenced by the thoughts of Marketing Mix 4Ps as most of domestic enterprises, including textile and garment exporters. This marketing strategy is being applied by most of enterprises at the present and the relation among the factors involved in the supply chain is being ignored. However, it must be understood that relationship marketing is a rather new method in the world and in Vietnam as well. From the reasons above, this paper attempts to assess the roles and the impacts of relationship marketing on export performance in Vietnamese garment enterprises. We particularly question whether the supposed impacts are positive and significant. We 
finally discuss the measures that should be taken in order to improve the effectiveness of this marketing method in Vietnamese garment enterprises.

The rest of the paper is organized as follows. Section 2 introduces the theoretical frame-work. Section 3 presents the research methodology. Section 4 reports and interprets the obtained results. Section 5 discusses the implications of the results. Concluding remarks are given in Section 6.

\section{Theoretical Framework}

In the context that the world economic globalization process is being at a rate, competition on the market is becoming tougher and tougher, in order to subsist and develop on the market, enterprises, particularly Vietnamese enterprises, shall have to build and promote their resources and competitive edges. An effective business network based on close cooperation relations among the members shall probably meet the aforesaid demand of enterprises. Having "relations" with foreign importing partners is very essential for enterprises involved in export operations when facing international competing factors, tariff barriers and especially non-tariff barriers in terms of language, culture, trade and consumption habits... These difficulties and challenges obstruct the building and developing the strong trading partnership between our country's garment enterprises with international distributors and importers. This is also the premise for applying the relationship marketing strategy to garment exporting enterprises of our country.

Vietnam is among the potential economies and is in the transition to socialism. Starting with economic transform in the late 1980s, the economy of Vietnam has achieved drastic growth rates, gradually integrating with the regional and international economy. This process was promoted from the mid-90s and marked by timeline when our country and the United States normalized the bilateral relations and when Vietnam joined regional and international organizations such as ASEAN, WTO. Vietnamese enterprises are continuously participating in international trading operations so as to improve economic effectiveness and promote the internationalization process of enterprises and integration of the country. One of the industries with strongest internationalization is garment - the staple export of Vietnam. Along with promoting strategies for products, models, categories and prices, more and more attention is being paid by Vietnamese garment enterprises to expanding cooperation with international enterprises and organizations so as to improve their export performance. It can be said that "relations" has become a factor that has decisive influence on the export performance of enterprises in general and Vietnamese garment enterprises in particular.

In general, there are many of factors that influence on enterprise export value: climate (attraction of market, culture, and consumer's habits), enterprise features (exports guaranty, quality, resources, scope, international market experience, knowledge and information) and marketing strategy. Leonidou et al. (2002) argue that export management is a process of managing relations with foreign customers and relevant parties having operations inside or outside the supply - distribution chain of enterprises. A balanced set of relations is an important target when participating in international markets in order to ensure stability and sustainable development. Research by Styles and Ambler (2000) analyzed export performance under the impact of two key elements: market (nation) and relations with distributors; the authors also pointed out that relations play an important role in enterprise export performance.

Although still a novelty in Vietnamese, as a matter of fact, the term of "relationship marketing" did come into existence over 50 years ago in Europe under various names such as "customer-centered management method" or "method for managing relations". This method was officially referred to in the United States since the 1980s, nonetheless, in view of universalization, as being widely applied recently, this method is based on the principal point of view and definition: Marketing is a process of establishing, maintaining and strengthening relations with customers and relevant partners so as to meet the objectives of the members involved in such organic relations (Grönroos, 1994). The relations among these members in the course of business exchanges become the core issue of marketing strategy. In his analysis, Berry (1983) stressed: attracting customers is just an intermediate step of the marketing cycle; the main purpose of enterprise is to maintain its relations with customers. Under this point of view, relationship marketing is defined as a process of establishing, maintaining, developing and strengthening relations with customers and partners for profit and parties can achieve the goals they pursue. Specifically, establishing relations involves guaranteeing with customers and partners, maintaining the relations on the basis of confidence formed from the fulfilled commitments and finally, strengthening the relations is synonyms with to continue guarantee in the future.

Thus, relationship marketing is a marketing method aimed at establishing and managing long-term relations and confidence with customers, suppliers and other factors in the market as well. Within the scope of this subject, the author focuses on analyzing relations between enterprise and its customers - the basic and most important 
relationship for each enterprise. The aim of relationship marketing is to bring about long-term value for customers, and constant customer satisfaction is the measure of success to the enterprise (Murphy et al., 2005).

Concerning the benefits of relationship marketing method, as to enterprises, as mentioned above, this method is aimed at establishing strong relations with existing customers, trying to strengthen their trust in product quality and encourage them to reuse enterprises' products. At the same time, during their relations with customers, enterprises can gather information, comments on product quality, from which to have product modifications accordingly and can best meet practical customer needs. On the other hand, once having their trust and loyalty to enterprises' products, customers will become the most effective marketing agents for enterprises' present and future products. In this way, enterprises can not only save their advertisement and promotion expenses, improve product quality and customer satisfaction but also gather information, penetrate into the market to gain advantages in terms of scope as well as sustainable competitive edges, since relations are potential resources which can hardly be imitated and traded (Fontenot \& Hyman, 2004). As to customers, relationship marketing method also brings about a lot of important tangible and intangible benefits such as trust, assuredness in terms of enterprises' product and service quality; intangible benefits such as close relationship, friendship of enterprise staff members, entitlement to handling services, preferences in terms of services, prices...

In order to assess relationship marketing operation of an enterprise, the following factors should be analyzed in detail: market knowledge, experiences, international investment commitment, trust, long-term orientation and cooperation) (Brencic et al., 2008).

Market knowledge: To subsist and develop, enterprises have to constantly be responsive to market changes. Market knowledge therefore plays an extremely important role in enterprises' business operations. Once involved in export market, the role of such knowledge is displayed more clearly in modifying and accommodating enterprises' products to government regulations, technical barriers, customer needs, as well as differences in language and culture. Hence, it has been confirmed by marketing experts and researchers that international market knowledge constitutes one of the most decisive factors to the export performance of an enterprise.

Experience: Basic knowledge means general knowledge involving various kinds of knowledge applicable to enterprises when penetrating in a certain international market. To some extent, it can enable enterprises to promote internationalization activities and to improve their export performance as well. In relation with market knowledge, experiences also occupy an especially important position in the initial period of export process when enterprises do not have much knowledge about the market. In this period, the experiences that enterprises have gained through relationships would become an essential resource helping them penetrate successfully into international markets. It has been proved by some research that expense constitutes part of market knowledge, is an important factor that decides export performance, and is often exchanged, accepted through interactions (Blankenburg \& Eriksson, 2000). In a more specific manner, Johanson and Vahlne (1977) argued that enterprises begin their export process by establishing relationships; these would enable them to gain experiences about the target international markets through interactions with international factors.

The positive impact of the buyer-seller partnership and export performance of enterprises was observed by some other authors (Amine \& Cavusgil, 1986; Style \& Ambler, 1994). Zahra et al. (2000) and Blomstermo et al. (2004) also confirmed the importance of experiences as an element for promoting the distribution of resources in enterprises in an efficient and effective manner. It therefore can assure the smooth operations and sustainable development of enterprises at international markets. Among the kinds of knowledge and experiences, special attention should be paid to the knowledge about business networks (Jannson, 2007), since as usual, such knowledge, experiences can only be obtained through social relationships and business co-operation.

According to the above mentioned research, it can be concluded that market knowledge, involving basic knowledge and experiences, shall be one of the essential factors for enterprises to step up their internationalization process as well as to promote their export operations and improve export performance.

Commitment, trust, long-term orientation and cooperation: Commitment to investment by way of approaching relationship marketing is displayed in two aspects. Commitment to continuing business on international market and commitment in relationships with partners such as distributors and customers. Commitment to market investment is based on the knowledge about international markets, in particular, under the impact of basic knowledge and experiences of enterprises. Commitment to relationships displays the intensity of relationships of enterprises with providers or distributors as well as trust or confidence among the factor above. In relationship marketing, intensity of relationships is considered as a general goal that should be achieved among the factors (seller, buyer or distributor) under the rule: the higher the trust in relationships the more sustainable the 
commitment to the market and partnerships (Style \& Ambler, 2000). The parties involved have the trust that the relationships established are important and have business value at present and in the future. They would commit themselves to maintaining, strengthening them on the voluntary basis for long-term benefits, putting aside some immediate interests to ensure sustainable stability of the relationships as well as the operation of the whole cycle of import-export and transactions on the international market.

International markets, characterized by various cultures, have more latent risks than domestic market, partly because of enterprises' insufficiency of import market information. Trust, therefore, plays a very important role, which can be displayed through readiness for sharing information, identifying goals and point of view on solving problems among partners. Research has proved that enterprises with great successes often have good relationships with international distributors and are always responsive to market changes. Requirements between partners and enterprises show high commitments in business relationships (Miyamoto \& Rexha, 2004).

In conclusion, establishing and maintaining commitment, trust, long-term orientation and cooperation become the core of marketing operations of enterprises for the time being, particularly in the period competition shifting from domestic market to international market and from competition among enterprises to competition among enterprise groups. As to export garment enterprises, relationships, as assessed, exert positive influences on their export performance.

\section{Methodology}

\subsection{Research Field}

2010 was a prosperous year for the Vietnamese garment industry: Garment exports reached USD 11.2 billion, increasing by $23.2 \%$ compared with that of 2009 ; and for the first time, Vietnam was among the world's Top Five in terms of garment export turnover. With the results achieved, the Vietnamese garment industry proved its role in the total export turnover of the whole country. Textile and garment exports of Vietnam reached an especially high growth rate, from USD 2 billion in 2001 to over USD 11 billion in 2010. And by 2010, the textile and garment surpassed oil and gas to become the industry with greatest export turnover among the 18 staple commodities for export in 2010 , contributing $15.6 \%$ to the total export turnover of the whole country. Continuing its impetus to development, in 2011, textile and garment export turnover of Vietnam reached USD 14 billion, for the first 7 months of 2012 only, this figure was USD 8.27 billion. Despite the fact that the world and Vietnamese economy are facing many difficulties in recent years, thus having great impact on the textile and garment industry, textile and garment enterprises are making every effort to retain their stable growth rate and make great contributions to the export turnover of the whole country.

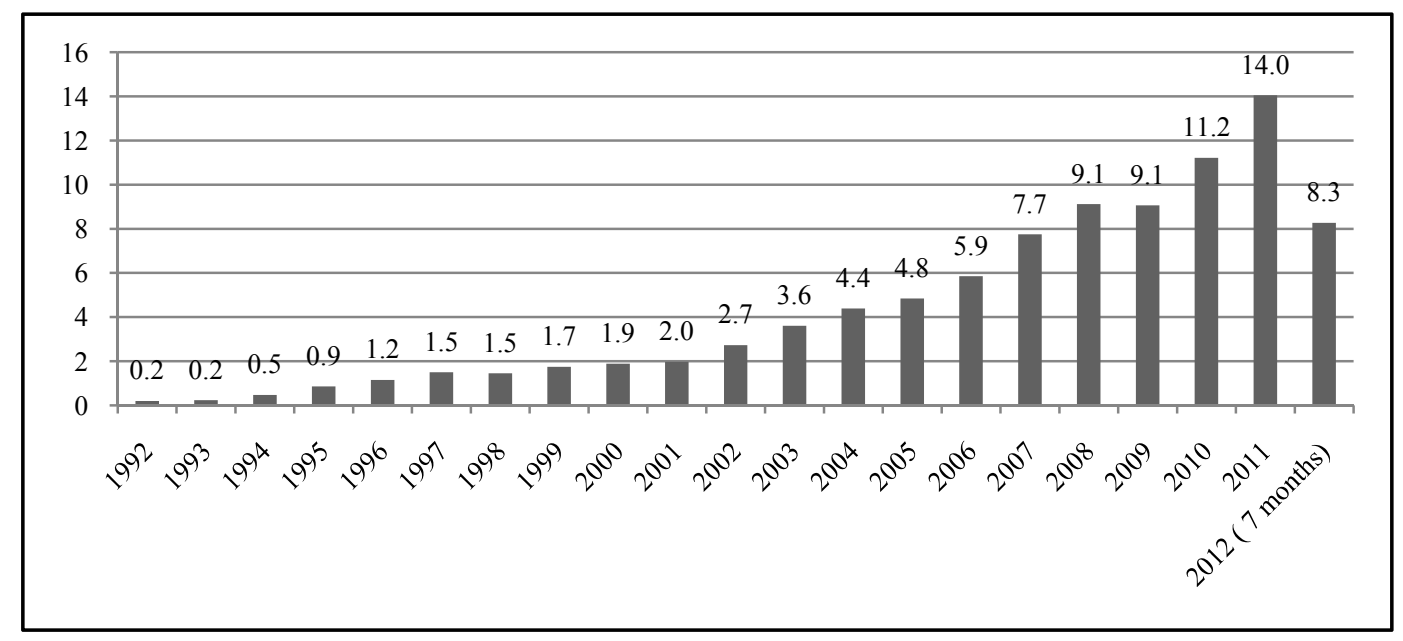

Figure 1. Textile and garment exports of Vietnam in the period 1992-2012

Source: General Statistic Office of Vietnam.

The United States, Japan and EU are always key markets, accounting for the highest rate of total export garment turnover of Vietnam. In 2011, Vietnam's garment exports to the American market reached USD 6,883.6 million, accounting for nearly $50 \%$ of total export garment of Vietnam; to the Japanese market: USD1,690.3 million, over $12 \%$; to EU: USD 2,522.7 million, $18 \%$. This indicates that garment exports to these three large markets brought about great revenue for the country as well as important contributions to export value of Vietnam in general. 


\subsection{Data Collection and Research Sample}

In order to assess the role of relationship marketing and its actual application to Vietnamese garment enterprises, the subject employed the quantitative research method combined with interviews. Research process was carried out in three steps. Firstly, in the initial period, we conducted documental research on related articles, subjects, monographs, and from the information gathered, establish questionnaires for survey. The questionnaires continued to be approved and refined via exchanges, open interviews with a number of typical Vietnamese experts and entrepreneurs.

The official questionnaire included 52 questions concerning general information and relationship marketing operations in Vietnamese garment enterprises. The questions are about the issue of establishing and maintaining relationships of enterprises on international markets as well as export performance, market knowledge level (technical barriers, information about level of competition, risk when joining foreign markets, distribution system...) and support from the government... The questions concern the importance, performance and stability (except for some questions concerning general information about enterprises) with scales from 1 to 5 as in table 1.

Table 1. Scales of questions

\begin{tabular}{rrrr}
\hline Scale & Effectiveness & Importance & Stability \\
\hline 1 & Very low & Unimportant & Very instable \\
2 & Low & Less important & Instable \\
3 & Average & Average & Average \\
4 & Good & Important & Stable \\
5 & Very good & Very important & Very stable \\
\hline
\end{tabular}

Secondly, questionnaires are delivered to Vietnamese garment production and exporting enterprises nationwide. Such companies are selected basing on their relative stable business lines and scope. To increase the rate of correct answers, numerous methods are employed by the subject such as by post, e-mail, direct contact, telephone to introduce and instruct enterprises on how to fill the questionnaires. As a result, contacts were conducted and as many as 141 enterprises were involved in answering the survey questionnaires.

Thirdly, summing up and reviewing the questionnaires answered. 7 questionnaires were disqualified for insufficient information; finally the sample size was fixed with 134 Vietnamese garment exporting enterprises. Data was entered, saved and processed on the SPSS statistic software and the analytic results are shown in the later part of the subject.
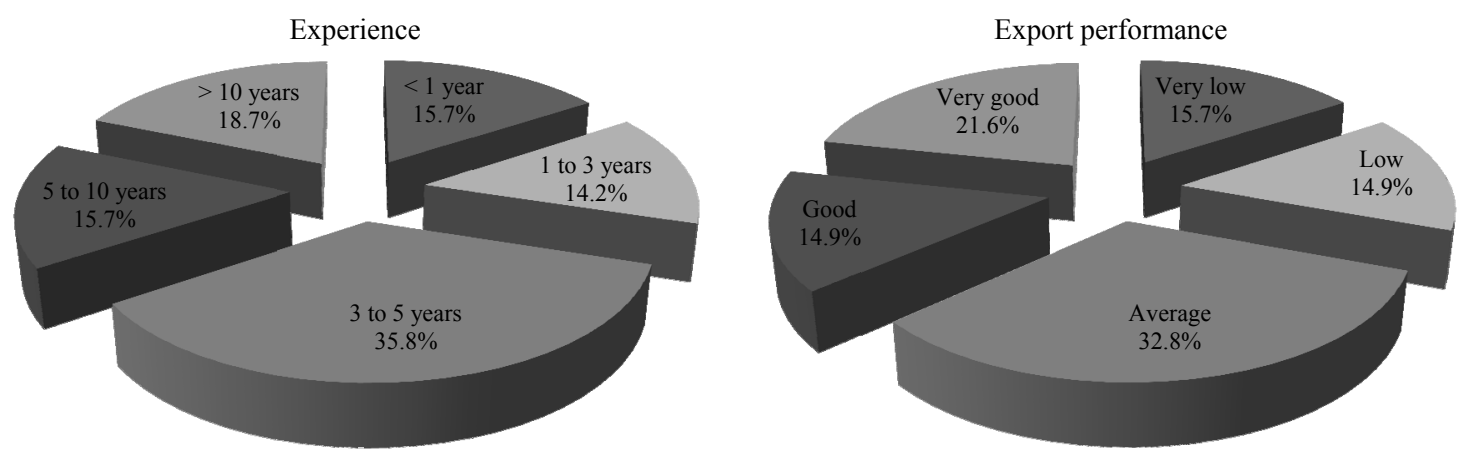

Figure 2. Sample of survey

\section{Results and Interpretations}

Through summing up and statistical analysis of the data collected, research results were focused on the two key points: Real situation of export performance and role, real situation of applying relationship marketing in Vietnamese garment exporting enterprises. Real situation of export performance was assessed via sales revenue, rate of export on sales revenue and satisfaction of enterprises with export performance in general. Survey results have shown that sales revenue of the garment exporting enterprises involved in the survey averaged VND $10-$ 
50 billion per year (50/134 enterprises, accounting for 37.3\%), a number of enterprises had high sales revenue, between VND 50-100 billion (16.4\%) and over VND 100 billion (17.9\%). These were very high rates; however, as judged by enterprises, export performance only reached a relative level, with points averaging $3.12 / 5$. These results were in fact rather modest for such a key export sector of our country. In order to explore the cause of the above-mentioned situation, in relationship marketing approach, the assay continues analyzing elements concerning international market knowledge, commitment, trust, long-term orientation and cooperation in the business network of Vietnamese garment exporting enterprises.

International market knowledge involves information about foreign markets, knowledge about technical barriers of international markets, possibility of penetrating into the markets, possibility of contacting customers, product distribution channels, price competition of products, customer habit knowledge... in which, barriers of countries to imported products are the issue of greatest concern of enterprises, particularly non-tariff barriers. As judged by economists, a system of technical barriers is the most effective method for limiting goods imported from developing countries. This is also the biggest challenge and difficulty that are confronting Vietnamese textile and garment exporting enterprises on international markets like the EU (European Union) and the United States. There is a satisfactory result, i.e. most the Vietnamese enterprises involved in the survey have indicated that they have the knowledge of all three technical barriers to export garment goods, including technical regulations as technical requirements that have to compulsorily be applied; technical standards as technical requirements approved by an accredited organization but not compulsorily be applied; and conformity assessment procedure for a kind of commodity in accordance with technical regulations / standards (according to WTO). Nevertheless, when asked about the real situation and potential to be responsive to the above mentioned international technical barriers, it was judged by the enterprises that the real situation and possibility of being responsive for the time being are not high, only scoring 3.02 points, i.e. an average level.

Table 2. Survey inspection results

\begin{tabular}{lccc}
\hline & Quantity & Average value & Standard deviation \\
\hline Satisfaction of export performance & 134 & 3,12 & 1,338 \\
Satisfaction of turnover & 134 & 3,01 & 1,254 \\
Assessment of export operation & 134 & 3,12 & 0,910 \\
Assessment of advertisement operation & 134 & 3,00 & 1,069 \\
Assessment of garment product quality & 134 & 3,55 & 1,148 \\
Trust on foreign partner & 134 & 2,78 & 1,218 \\
Point of view on division of profits with partner & 134 & 2,93 & 1,322 \\
Length of time of relationship with partner & 134 & 3,04 & 1,370 \\
Point of view on long-term cooperation & 134 & 3,06 & 1,408 \\
Intensity of personnel with partner & 134 & 2,99 & 1,387 \\
Information exchange level & 134 & 3,40 & 1,239 \\
Level of co-work with partner & 134 & 2,94 & 1,296 \\
Intensity of visit to partner & 134 & 3,04 & 1,348 \\
International market knowledge & 134 & 3,03 & 1,398 \\
Possibility of penetrating international market & 134 & 3,06 & 1,413 \\
Possibility of promoting international trade & 134 & 2,99 & 1,286 \\
Knowledge of international consumer habit & 134 & 3,05 & 1,345 \\
Knowledge about international distribution system & 134 & 2,97 & 1,292 \\
Capacity of competition & 134 & 4,18 & 0,703 \\
Capacity of price competition & 134 & 4,18 & 0,670 \\
\hline
\end{tabular}

Besides the information about barriers, other information and knowledge relating to capacity of competition, responsiveness to the market and market risks must also be analyzed to assess market knowledge level of Vietnamese garment enterprises. When referring to the possibility of penetrating into the markets, it was believed by the enterprises that their ability to succeed upon contacting customers and bringing their products into the markets was very high, up to $56 \%$ of the enterprises, when asked, judged that this ability of theirs was good and very good. Survey analysis and investigation continued bring about positive results concerning customer habits of international customers: $52 \%$ of the enterprises believed that they had good and very good knowledge about consumer habits and were ready to provide appropriate products that can satisfy such international clienteles.

Apart from that, Vietnamese garment enterprises are also knowledgeable the distribution channels at importing markets: $38.1 \%$ of the enterprises said that they had thorough knowledge; $26.1 \%$ thought their knowledge about 
this field involving all distribution channels. Based on their knowledge about market features and distribution system, Vietnamese garment exporting enterprises are self-confident that their competitiveness, particularly in terms of prices, with foreign enterprises is fairly high (4.18 points). However, their capacity of penetrating into the market and promoting trade just achieve an average level of 3.06 and $2.99 / 5$ points respectively.

A general view of the real situation of Vietnamese garment exporting enterprises has revealed numerous positive patterns in gathering information about the markets as well as capacity of competition of Vietnamese enterprises on the world markets. This is the result of the efforts made by enterprises in recent years. According to the interviewed experts and enterprises, they have strongly invested in marketing mix strategy 4Ps. Nonetheless, according to survey questionnaire results, the real situation is that Vietnamese enterprises still lack international market information: $39.6 \%$ was self-confident to understand clearly and very clearly, their average patterns reached 3.03 / 5 points only. This may be one of the main causes of the fact that the export performance of Vietnamese garment exporting enterprises was not up to the expectation in recent years.

According to relationship marketing approach, the subject concentrates on analyzing the role of the components of business cooperation relations between Vietnamese garment enterprises and foreign importing, distributing partners. These elements include trust, commitment, long-term orientation and cooperation, which, as assessed, are the most sustainable elements for establishing cooperation relations with foreign partners. If international market knowledge is marked by its macroscopic characteristics, reflecting the general knowledge of partner (culture, habits...), then trust, commitment, long-term orientation and cooperation reflect in detail the quality of relationships of Vietnamese garment exporting enterprises with foreign partners.

Investigation results have revealed a sad situation, i.e. the level of trust or confidence of Vietnamese garment exporting enterprises in foreign partners is rather low, the average mark was just 2.78 / 5 points. Specifically, up to 56 Vietnamese enterprises (41.8\%) believed that their level of trust in foreign partners was low and very low. Similarly, investigation results of commitment to partner also reached the average mark of 3.06/5 points; when asked, 58.2\% of the enterprises had wrong point of view on relationship "only at a temporary level", without demonstrating the effort to establish and maintain relationships. The inevitable consequence is orientation and cooperation between Vietnamese garment exporting enterprises and their partners were at an average level of $3.04 / 5$ points, only $40.3 \%$ of enterprises could maintain their long-term and sustainable cooperation.

It is obvious that between the two key elements of relationship marketing there is a mutual organic relationship. However, in an attempt to find out the main cause of the situation above, the assay analyzes in detail several elements, also known as methods of establishing, strengthening and maintaining cooperation relations with foreign partners. These methods cover: Exchanging information, visiting, sending and receiving personnel, mutual activities of exploring the market and promoting sale.

Assessment results of activities for exchanging information between Vietnamese enterprises and their partners were inhomogeneous with summing up results of relationships. Enterprises were of the opinion that information exchanges between them and their foreign partners take place on a regular basis, with average mark reaching $3.4 / 5$ points; specifically, up to $47.8 \%$ of enterprises keep regular and constant information exchanges with their partners; $29.9 \%$ said such activity at their enterprises was enough and appropriate. In practice, regular information exchanges are among the most important activities that contribute to establishing and developing sustainable relationships with partners upon joining international markets. Apart from exchanging information, that the parties are involved in exploring the market together also helps consolidate trust and strengthen their relationships, as well as gather important and necessary knowledge of the markets. This activity however is not actually effective as up to 51/134 enterprises believed that it was carried out at an indifferent level (the average mark reached $2.94 / 5$ points). This was one of the causes of the shortcomings existing in the cooperation relationships among Vietnamese garment exporting enterprises.

Two other elements that demonstrate trust and commitment of the parties are intensity of visiting partner and sending and receiving personnel for learning about each other. In the opinion of the experts and enterprises interviewed, these are two most effective tools for developing and maintaining the cooperation relations among the parties. Investigation results have revealed that enterprises' employees and their partners had very few contacts, with the average mark reaching $2.97 / 5$ points. The main cause lies in the language and culture barriers. In reality, the reciprocal exchanges among employees bring about numerous benefits, this activity not only facilitated mutual understanding between individuals and enterprises but also partially promote information exchange among the parties involved in the business network. Nevertheless, according to enterprises, direct visits at the leadership level will be more essential and this is the most important measure taken by Vietnamese enterprises to establish relationships on international markets. Through such visits, parties may exchange 
information, strengthen their mutual understanding and relationships. Owing to the essential role of this activity, it has been revealed by the majority of enterprises involved in the survey that their visits to foreign partners were always maintained at a moderate level whilst for some other enterprises, this was kept on a regular basis.

With an overview of the real situation of exports by Vietnamese enterprises, investigation results have shown that though reaching a certain level, this does not match up with the potential of a key export sector of our country. The cause of this station is due partly to the poor market knowledge of Vietnamese enterprises and due chiefly to their restricted point of view on establishing and developing business cooperation relations with foreign partners. These constitute challenges to Vietnamese garment exporting enterprises, especially at the moment when they go together with the current global financial crisis.

\section{Implications of the Results}

Based on survey findings of the real situation of exports in relationship marketing approach, the assay proposes some recommendations for Vietnamese garment exporting enterprises to further improve and strengthen their export performance. Apart from that, this also needs support from the Government, authorities and concerned agencies.

\subsection{Efforts Made by Export Garment Enterprises}

\section{- Strengthening export marketing activities}

Export marketing activities should be focused on market research, since this is one important activity with the role of providing necessary information to help enterprises make most exact decisions to select marketing strategy suitable for each international market segment. Specifically, i.e. information about market size, market potential, trade barriers, from that to have proper measures to improve business performance. Relevant information is available for enterprises from the following sources:

Vietnam Chamber of Commerce and Industry (VCCI), trade representatives or Vietnam embassies in countries over the world. Theses shall be agencies responsible for promoting business and economic cooperation between Vietnam and other countries, thereby can provide basic and reliable information for Vietnamese garment exporting enterprises;

Textile and garment organizations and associations, such as Vietnam Textile and Apparel Association (VITAS), Vietnam National Textile and Garment Group...;

- Governmental and non-governmental organizations specializing in market research and prestige on foreign markets;

- Publications, professional magazines, Internet;

- And others, for example, experts on missions overseas for market survey or representative offices of consulting enterprises in countries.

Enterprises should set up a professional export marketing section, since marketing activity in the home country itself is very complicated resulting from tough competition. Things become more difficult when enterprises are engaged in international markets and confronted with various challenges in terms of culture, politics, environment, religion, etc. Also, enterprises can hire professional marketing companies at the markets in which they go for export activity, make good use of their experts in the field of marketing, and furthermore, as they are local enterprises, they have basic and sounder knowledge about the markets.

- Establishing and strengthening relationship marketing

In strategies for export marketing, relationship marketing needs to be strengthened in Vietnamese garment for export production enterprises; specifically, by building trust in partners and maintaining commitment to market and to long-term cooperation as well. To realize this, the first thing for Vietnamese garment export production enterprises to do is to change their thought, conception of business cooperation in the tendency towards sustainability, cooperation and mutual benefits. In more details, trust between partners during cooperation process will be the prerequisite for enterprises engaged in international markets in general and garment exporting enterprises in particular can establish long-term strategic cooperation relations for improving export performance. Nonetheless, building trust in foreign partners is not simply to change thought but to turn into specific actions which parties can observe and assess.

To create trust, Vietnamese enterprises have to:

- Improve product and service quality: Product quality is the primary element for creating and maintaining trust with trade partners, since this is the value which they (or ultimate customers) expect to receive. Enterprises therefore have to unceasingly improve product quality and supporting service quality so as to meet requirements 
of partners as well as widely used international regulations and standards; for example, to apply international quality management systems to assure that once brought into foreign markets, products will always best satisfy customer requirements.

- Create trust and commitment to mutual cooperation: Throughout the assay, and as the basic, primary element of the relationship marketing model, is the level of trust between the parties. Trust is a qualitative term, very difficult for measurement and assessment. Hence, in economy, it is usually associated with commitments by parties, presenting material and spiritual values in relationships. And in order to have trust, the parties must assure their faithfulness in relationships, first and foremost, through activities of promoting relations and exchanging information.

- Strengthening information exchanges: Through process of exchanging information, partners in the business network will have a better understanding of each other, from which to strengthen the trust between them. Information exchanges can be performed by many methods: first, through direct visits. Vietnamese enterprises should pay more regular visits to their partners for mutual information exchanges, for solving problems, inquiries or misunderstandings that still exist together. Direct dialogues are also an effective method for exchanging information, creating and developing trust and confidence among partners. In addition, sending, receiving or exchanging personnel should also be employed. Together with direct activities of promoting relationships, indirect activities by e-mail, telephone should be used frequently, since these are effective measures to save expenses and time. Agents at foreign representative offices should establish good individual relationships with others in their enterprise partners. Reality as well as research have proved that mutual trust is built on the basis of good relationships of individuals, as individuals constitute the foundation and manage the enterprise machine, too.

- Building up highly qualified personnel with high sense of cooperation: Besides the activities mentioned above, Vietnamese garment exporting enterprises should pay attention to personnel training and management work, since they are the ones who directly work with and contact foreign partners. Their qualification and attitude therefore will have direct influence on the mutual relations.

With the trust created, enterprises will have concrete commitments to their partners and to the markets to ensure the operation and sustainability of business cooperation relations. This is represented through commitments to spirit, material, benefits, as well as contributions of the parties during cooperation process. To achieve this, Vietnamese enterprises should give positive contributions to the cooperation process, probably in the forms of finance, techniques, technology or know-how...From time to time, enterprises should sacrifice some immediate benefits (profit, short-term sales) for assurance of long-term cooperation between the parties, proceeding from that, to improve the roles of relationships, make it possible for improving export performance.

\subsection{Supports from the Government and State}

To achieve strong and sustainable cooperation for mutual benefits, in addition to efforts made by Vietnamese export garment enterprises; there need to be support from the Government, the authorities and concerned agencies. First, the Government and the State should draw up and agree upon policies, mechanisms for promoting export activities, make it possible for enterprises to have chance of accessing international markets. Specifically, the State should grant enterprises with support in providing information, developing infrastructure, building system of distribution and expanding consuming markets via embassies in countries or agencies in charge of trade, opening trade fairs to promote traditional crafts abroad, carrying out programs for promoting Vietnamese culture and people. Support as such shall be especially essential for enterprises to obtain market information as well as to get access to international partners.

In addition, the Government and concerned agencies should also organize numerous activities of promoting trade, trade fairs, as well as exchanges and learning about experiences between Vietnamese garment export enterprises and foreign partners to promote mutual cooperation relations. Activities as such are cooperative and also testimonies to the trust of enterprise partners.

\section{Concluding Remarks}

Enterprise export performance is decided not only basing on quality, use value of product but also various relevant elements such as trade barriers, culture, customer habits, and primarily the mutual relationships between the parties during import-export process. Cooperation relations on international markets between exporters and customers being enterprises are governed by such elements as knowledge, information, trust, commitment to long-term cooperation among the members in the network. This assay focuses on analyzing the role of relationship marketing activities and export performance of Vietnamese garment exporting enterprises. 
According to survey findings, it can be confirmed that though some certain successes have been achieved in maintaining and promoting export performance, the export performance of Vietnamese enterprises is still restricted, on the one hand this is partly due to some objective elements, on the other hand, because they have not established a reliable, sustainable strategy for cooperation relations with foreign partners.

The subject also proposes some recommendations so as to improve the export performance of Vietnamese garment exporting enterprises, more importance should be attached to relationship marketing activities, particularly, activities of gathering and exchanging market information, from which to form and develop reciprocal commitments between the concerned parties. Along with efforts from enterprises, the Government should also bring into play its role in supporting, establishing strategic relationships at macro level with countries as key and potential markets in order to further step up the export performance of Vietnamese garment exporting enterprises.

\section{References}

Amine, L. T., \& Cavusgil, S. T. (1986). Export Marketing Strategy in the British Clothing Industry. European Journal of Marketing, 20(7), 21-33. http://dx.doi.org/10.1108/EUM0000000004653

Berry Leonard. (1983). Relationship Marketing. American Marketing Association, Chicago.

Blankenburg, H., \& Eriksson, K. (2000). The Character of Bridgehead Relationships. International Business Review, 9(2), 191-210, http://dx.doi.org/10.1016/S0969-5931(99)00036-0

Blomstermo, A., Eriksson, K., Lindstrand, A., \& Sharma, D. (2004), The Perceived Usefulness of Network Experiential Knowledge in the Internationalizing Firm. Journal of International Management, 10, 355-373. http://dx.doi.org/10.1016\%2Fj.intman.2004.05.004

Brencic, M. M., Ekar, A., \& Virant, V. (2008). The Influence of Relationship Marketing Components on Export Performance: A Comparison of Transitional vs. Established Markets. Scientific papers.

Fontenot, R. J., \& Hyman, M. R. (2004). The antitrust implication of relationship marketing. Journal of Business Research, 57, 1211-1221. http://dx.doi.org/10.1016\%2FS0148-2963\%2802\%2900454-X

Grönroos, C. (1995). Relationship Marketing: The Strategy Continuum. Journal of the Academy of Marketing Science, 23(4), 252-254. http://dx.doi.org/10.1007\%2FBF02893863

Jannson Hans. (2007). International Business Marketing in Emerging Country Markets. UK: Edward Elgar.

Johanson, J., \& Vahlne, J. E. (1977). The Internationalization Process of the Firm. Journal of international Business Studies, 8(1), 23-32. http://dx.doi.org/10.1057\%2Fpalgrave.jibs.8490676

Kotler, P. (2003). Marketing Management (11th ed.). Upper Saddle River, NJ: Prentice-Hall.

Leonidou, L. C., Katsikeas, C. S., \& Samiee, S. (2002). Marketing Strategy Determinations in Export Performance: A Meta-Analysis. Journal of Business Research, 55, 51-56, http://dx.doi.org/10.1016\%2FS0148-2963\%2800\%2900133-8

Miyamoto, T., \& Rexha, N. (2004). Determinants of Three Facets of Customer Trust: A Marketing Model of Japanese Buyer-Supplier Relationship. Journal of Business Research, 57, 312-319, http://dx.doi.org/10.1016\%2FS0148-2963\%2801\%2900327-7

Murphy, B., Maguiness, P., Pescott, C. H., Wislang, S., Ma, J., \& Wang, R. (2005). Stakeholder perceptions presage holistic stakeholder relationship marketing performance. European Journal of Marketing, 39(9/10), 1049-1059. http://dx.doi.org/10.1108\%2F03090560510610716

Styles, C., \& Ambler, T. (1994). Successful Export Practice: The UK Experience. International Marketing Review, 11(6), 23-4. http://dx.doi.org/10.1108\%2F026513394100729997

Styles, C., \& Ambler, T. (2000). The Impact of Relationship Variables on Export Performance: An Empirical Investigation in Australia and the UK. Australian Journal of Management, 25(3), 261-281.

World Bank Group. (2010). Better Work Vietnam: Garment Industry 1st Compliance Synthesis Report. International Finance Corporation, World Bank Group.

World Bank Group. (2011). Better Work Vietnam: Garment Industry 2nd Compliance Synthesis Report. International Finance Corporation, World Bank Group.

Zahra, S. A., Ireland, R. D., \& Hitt, M. A. (2000). International Expansion by New Venture Firms: International Diversity, Mode of Market Entry, Technological Learning Performance. Academy of Management Review, 43, 925-950. http://dx.doi.org/10.2307\%2F1556420 